\title{
Metastatic squamous cell carcinoma in two loggerhead sea turtles Caretta caretta
}

\author{
J. Orós ${ }^{1, *}$, S. Tucker ${ }^{2}$, L. Fernández ${ }^{3}$, E. R. Jacobson ${ }^{2}$ \\ ${ }^{1}$ Unit of Histology and Pathology, Veterinary Faculty, University of Las Palmas de Gran Canaria (ULPGC), and \\ ${ }^{3}$ Department of Animal Pathology, Veterinary Faculty ULPGC, Transmontana s/n, 35416 Arucas, Las Palmas, Spain \\ ${ }^{2}$ Department of Small Animal Clinical Sciences, College of Veterinary Medicine, University of Florida, PO Box 100126, \\ Gainesville, Florida 32610-0126, USA
}

\begin{abstract}
We received 2 stranded loggerhead sea turtles (Caretta caretta) with squamous cell carcinomas to necropsy. The dead turtles had been collected in Gran Canaria and Fuerteventura in April 1994 and May 1997, respectively to determine the cause of death. One turtle had 3 ulcerated lesions in the dorsal part of the neck and several irregular masses in the lungs and kidneys. Histologic examination of lesions in the skin, lungs, kidneys, and ventricular myocardium revealed neoplastic proliferation of abnormal keratinocytes. Ultrastructural examination identified the tumoral cells as epithelial cells. The second turtle had 4 lesions in the skin of the head and flippers, and several irregular masses in the lungs, liver, and kidneys. Histological examination revealed a squamous cell carcinoma with metastases to muscle tissue, liver, lungs, and kidneys. Attempts to characterize the tumoral cells by immunohistochemistry using several monoclonal and polyclonal antisera against high and low molecular weight cytokeratins from mammals, as well as vimentin and desmin, failed. Differences between reptilian keratins (mainly $\beta$-keratins) and mammalian keratins (mainly $\alpha$-keratins) could explain this absence of immunoreactivity. This is the first description of squamous cell carcinoma in sea turtles.
\end{abstract}

KEY WORDS: Squamous cell carcinoma $\cdot$ Loggerhead turtle $\cdot$ Caretta caretta $\cdot$ Sea turtle $\cdot$ Reptile $\cdot$ Immunohistochemistry

Resale or republication not permitted without written consent of the publisher

\section{INTRODUCTION}

Squamous cell carcinoma (SCC) is a malignant neoplasm of squamous epithelial cells that affects several domestic mammalian species, mainly dogs, cats, horses, and cows (Pulley \& Stannard 1990). In avian species, it has been detected most frequently in chickens (Hafner et al. 1993, Latimer 1994). SCC has also been reported in several amphibian species (Green \& Harshbarger 2001, Harshbarger \& Trauth 2002). In reptiles, SCC has been observed most frequently in snakes (Harshbarger 1979, Machotka 1984, Ramsay \& Fowler 1992) and lizards (Jacobson 1981, Machotka 1984). Chelonian species in which SCC has been reported include the Ceylon terrapin Geoyda trijuga (Cowan 1968), the European pond turtle Emys orbicu- laris (Billups \& Harshbarger 1976), and the eastern box turtle Terrapene carolina (Greenacre \& Roberts 2000).

Except for the green turtle fibropapillomatosis, neoplastic diseases are rare in sea turtles. Although fibropapillomatosis has been described for several species of sea turtles in Florida, Hawaii, Puerto Rico, Cayman Islands, Virgin Islands, Barbados, Venezuela, Colombia, Panama, Belize, Nicaragua and Australia (Jacobson 1991, Harshbarger 2002), there are no confirmed reports of fibropapillomatosis in Spain. Since 1994, the College of Veterinary Medicine, University of Las Palmas de Gran Canaria (ULPGC), has been conducting a survey of the pathology and causes of mortality among sea turtles stranded on the coasts of the Canary Islands, including the pathological and histopathological evaluation 
of 20 to 30 turtles per year. We report here the histopathological features of 2 cases of metastasizing squamous cell carcinoma in the loggerhead sea turtle Caretta caretta.

\section{MATERIALS AND METHODS}

Within a 3 yr period (i.e. in April 1994 and May 1997), 2 stranded loggerhead sea turtles with squamous cell carcinomas were submitted to the Veterinary Faculty, ULPGC. The first was a $6.5 \mathrm{~kg}$ juvenile female stranded in Gran Canaria $\left(27^{\circ} 40^{\prime} \mathrm{N}\right.$, $\left.15^{\circ} 20^{\prime} \mathrm{W}\right)$. The turtle had a curved carapace length and width of 33 and $31 \mathrm{~cm}$ respectively, and a straight carapace length and width of 29 and $28 \mathrm{~cm}$ respectively. After stranding, the turtle had been housed in an aquarium at the Wildlife Rehabilitation Center of Tafira, Gran Canaria. Physical examination had revealed anorexia and lethargy. Despite forcefeeding and intramuscular administration of antimicrobial enrofloxacin, the turtle died 1 wk after stranding. The second turtle was a $7.2 \mathrm{~kg}$ juvenile female found stranded dead in Fuerteventura $\left(28^{\circ} 10^{\prime} \mathrm{N}, 14^{\circ} 20^{\prime} \mathrm{W}\right)$. This turtle had a curved carapace length and width of 34 and $33 \mathrm{~cm}$ respectively, and a straight carapace length and width of 31 and of $30 \mathrm{~cm}$ respectively.

The gross postmortem examinations of both turtles were carried out using the protocol developed by Wolke \& George (1981). Fecal specimens were processed following techniques described by Boch \& Supperer (1982).

Macroscopic lesions were recorded and tissue samples from all major organs were fixed in $10 \%$ neutral buffered formalin, embedded in paraffin, sectioned at
$5 \mu \mathrm{m}$ for light microscopy, and stained with hematoxylin and eosin (HE) and periodic acid-Schiff (PAS) (Bancroft $\&$ Stevens 1996). Selected samples from the skin and lungs of the first turtle and from the liver of the second turtle were fixed in $2.5 \%$ buffered glutaraldehyde, routinely processed for transmission electron microscopy and embedded in epoxy resin. Ultrathin sections were mounted on grids, stained with uranyl acetate and lead citrate, and examined with a Zeiss 910 microscope.

We attempted to characterize the tumoral cells by immunohistochemistry using several monoclonal and polyclonal antisera against high and low molecular weight cytokeratins from mammals, as well as vimentin and desmin (Table 1). For immunohistochemical labelling, selected sections were deparaffinized and immersed in $\mathrm{H}_{2} \mathrm{O}_{2} 3 \%$ in absolute methanol for 30 min. They were then rinsed in phosphate-buffered saline (PBS) and placed in a solution of $0.1 \%$ protease, $\mathrm{pH} 7.2$, for $5 \mathrm{~min}$ at room temperature. The sections were washed 3 times in PBS, blocked with $5 \%$ normal goat serum for $30 \mathrm{~min}$, and exposed for $2 \mathrm{~h}$ to a panel of monoclonal and polyclonal antisera against the high and low molecular weight mammalian cytokeratins, vimentin and desmin (Table 1). The monoclonal antibodies were applied at dilutions ranging from 1:15 to 1:30; the polyclonal antisera were applied at dilutions ranging from 1:100 to $1: 200$. The sections were rinsed in PBS and incubated for 30 min with a 1:5 dilution of biotinylated antibody to mouse and rabbit IgG (LSAB Kit; Dako), rinsed again in PBS, and incubated for 30 min with a 1:5 dilution of streptavidin-peroxidase complex reagent (LSAB Kit). All incubations were at room temperature. After rinsing in PBS, the sections were exposed to 3-amino-9-ethylcarbazole (Sigma) as substrate. They were then counterstained with Mayer's hematoxylin and mounted using an aqueous

Table 1. Immunohistological tests on tumors of 2 sea turtles Caretta caretta. SCC: squamous cell carcinoma; -: negative; +: mild immunolabelling

\begin{tabular}{|c|c|c|c|c|c|c|}
\hline Antibody & $\begin{array}{l}\text { Monoclonal/ } \\
\text { polyclonal }\end{array}$ & Company & $\mathrm{SCC}$ & $\begin{array}{c}\text { Normal } \\
\text { epithelial } \\
\text { cells }\end{array}$ & $\begin{array}{l}\text { Normal } \\
\text { fibroblasts }\end{array}$ & $\begin{array}{c}\text { Normal } \\
\text { striated } \\
\text { muscular } \\
\text { cells }\end{array}$ \\
\hline $\begin{array}{l}\text { Keratin } \\
\quad \text { (Subtype 20) }\end{array}$ & Monoclonal & Dako & - & - & - & - \\
\hline $\begin{array}{l}\text { Keratin RCK } \\
\text { (Subtypes 5, 8) }\end{array}$ & Monoclonal & Euro-Diagnostics & - & - & - & - \\
\hline $\begin{array}{l}\text { Keratin NCL } \\
\quad \text { (Subtypes 8, 18, 19) }\end{array}$ & Monoclonal & Euro-Diagnostics & - & - & - & - \\
\hline Human keratin & Polyclonal & Euro-Diagnostics & - & - & - & - \\
\hline Vimentin & Polyclonal & Euro-Diagnostics & - & - & + & - \\
\hline Desmin & Polyclonal & Euro-Diagnostics & - & - & - & + \\
\hline
\end{tabular}


mounting medium (Immu-mount; Shandon). Normal tissues from mammals used as positive controls included skin, striated muscle and connective tissue. Negative-procedure controls consisted of applying antisera against other selected tissues from mammals, and the substitution of primary antibodies by normal goat serum or PBS.

\section{RESULTS}

The first turtle was cachectic at necropsy. On the dorsal side of the neck 3 ulcerated lesions were visible (Fig. 1). Several white and firm irregular masses, ranging in size from 1 to $2 \mathrm{~cm}$, were observed in the lungs, kidneys and heart. There was severe passive congestion of the liver. The gastrointestinal tract was empty. No parasites were observed in blood vessels or in the digestive tract. No lesions were visible in other organs. Fecal specimens evaluated by direct smear and fecal flotation did not contain protozoa or nematode eggs.

Histologic examination of the 3 ulcerative cutaneous samples revealed a neoplastic proliferation of abnormal keratinocytes arranged in cords and nests and associated with numerous mixed inflammatory cells. Invasive cords were formed by atypical cells most closely resembling those of the normal stratum spinosum. The majority of these cells were in direct contact with the dermis without a basal cell layer. Isolated 'horn pearls' were observed in some areas. Abnormal keratinocytes were round to polyhedral, had small amounts of eosinophilic cytoplasm, rounded or indented nuclei, and 1 or 2 nucleoli each. The mitotic index was approximately 1 to 2 mitosis per high-power field. No chromatophores were seen in the dermis of these ulcerative areas. Examination of the nodular lesions in the lungs demonstrated a neoplastic proliferation of keratinocytes arranged in

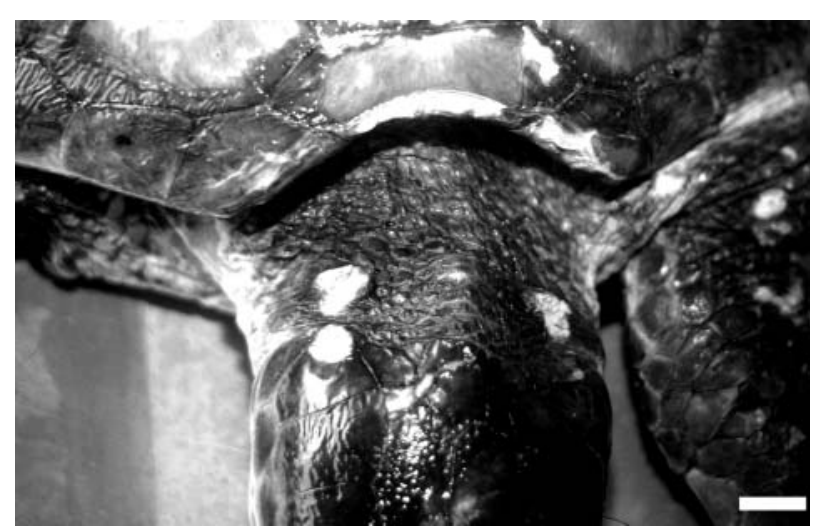

Fig. 1. Loggerhead Turtle No. 1, showing nodular ulcerated lesions in skin of neck. (Scale bar $=3 \mathrm{~cm}$ ) nests. Micrometastases and neoplastic cell emboli in pulmonary vessels were detected in other pulmonary areas (Fig. 2). Intercellular bridges (created by desmosomes stretched by artefactual cell shrinkage during histologic processing) were observed in the pulmonary micrometastases. The cytologic characteristics of the pulmonary nodules and micrometastases were similar to those of the cutaneous neoplasm. Interstitial pulmonary edema and mild interstitial pneumonia were observed. Variably sized masses of concentric layers of squamous epithelial cells showing gradually increasing keratinization toward the centers were observed in both kidneys and in the ventricular myocardium (Fig. 3). Some myocardial fibers surrounding some metastases displayed severe

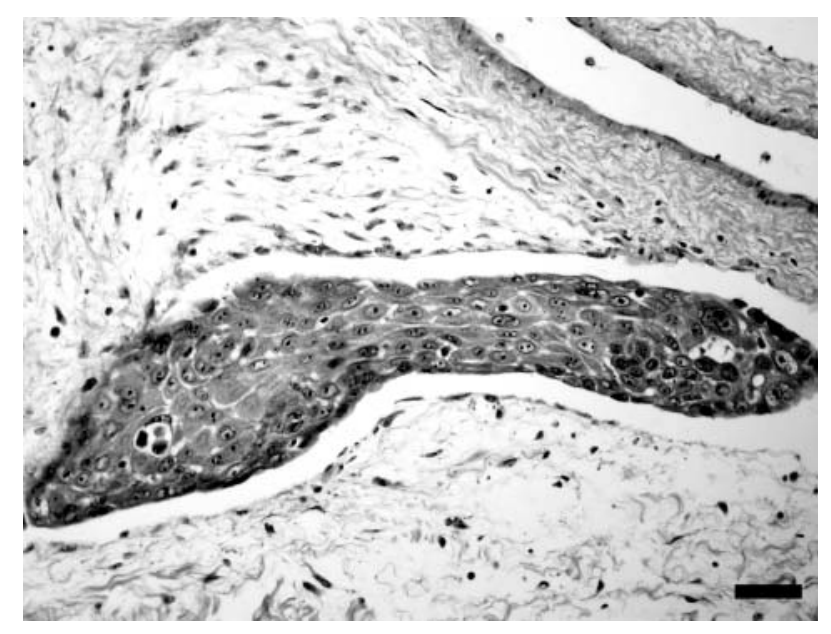

Fig. 2. Loggerhead Turtle No. 1, showing neoplastic cell embolus in septal pulmonary vessel. H\&E stain. (Scale bar = $35 \mu \mathrm{m})$

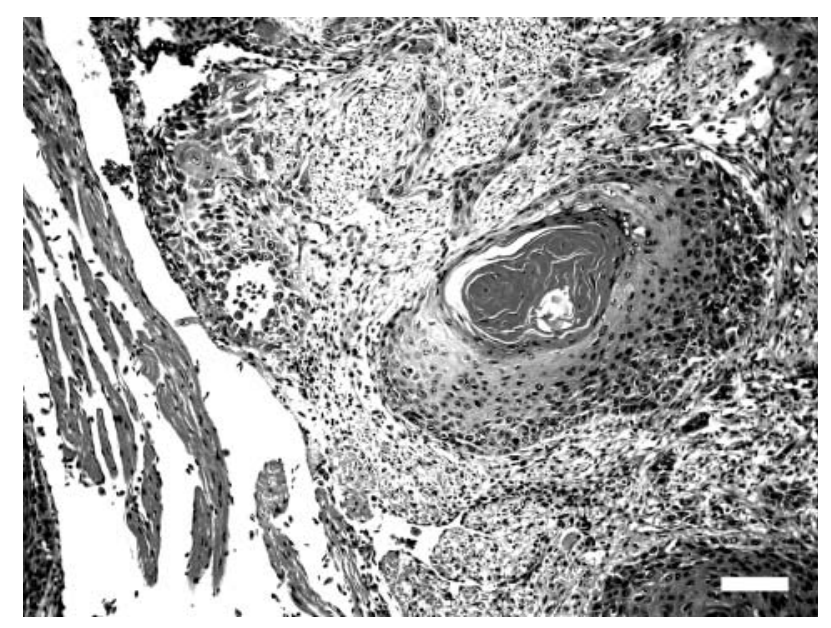

Fig. 3. Loggerhead Turtle No. 1, showing metastases composed of squamous epithelial cells with keratinization in the ventricular myocardium. Note irregular strands of squamous epithelial cells, probably outgrowths of the larger cornifying metastasis. H\&E stain. (Scale bar $=85 \mu \mathrm{m})$ 
degeneration associated with severe inflammatory reaction.

Ultrastructural examination of the neoplastic cells in the skin and lungs revealed morphological characteristics that included numerous desmosomes and tonofilaments, consistent with the cells being epithelial in origin (Fig. 4). The diagnosis was multiple $(\mathrm{n}=3)$ well-differentiated squamous cell carcinoma with metastases to lungs, kidneys, and the ventricular myocardium.

The second turtle had 4 white, variably sized lesions in the skin of its head and flippers; 2 of the cutaneous lesions were ulcerated. Several white and firm irregular masses, ranging in size from 1 to $1.5 \mathrm{~cm}$, were observed in the lungs, liver and kidneys. The spleen was enlarged and friable. No parasites were observed in blood vessels or in the digestive tract. No lesions were visible in other organs. Fecal specimens evaluated by direct smear and fecal flotation did not contain protozoa or nematode eggs.

Light microscopy revealed that all the cutaneous lesions were composed of anaplastic epithelial cells arranged in nests infiltrating the dermis (Fig. 5). Tumoral cells had nuclear hyperchromasia and prominent nucleoli. In some areas, stromal fibrosis was detected around the invasive neoplastic cells. In other dermal areas we observed edema and dilatation of the lymphatic vessels around the tumoral nests. Irregular cords of

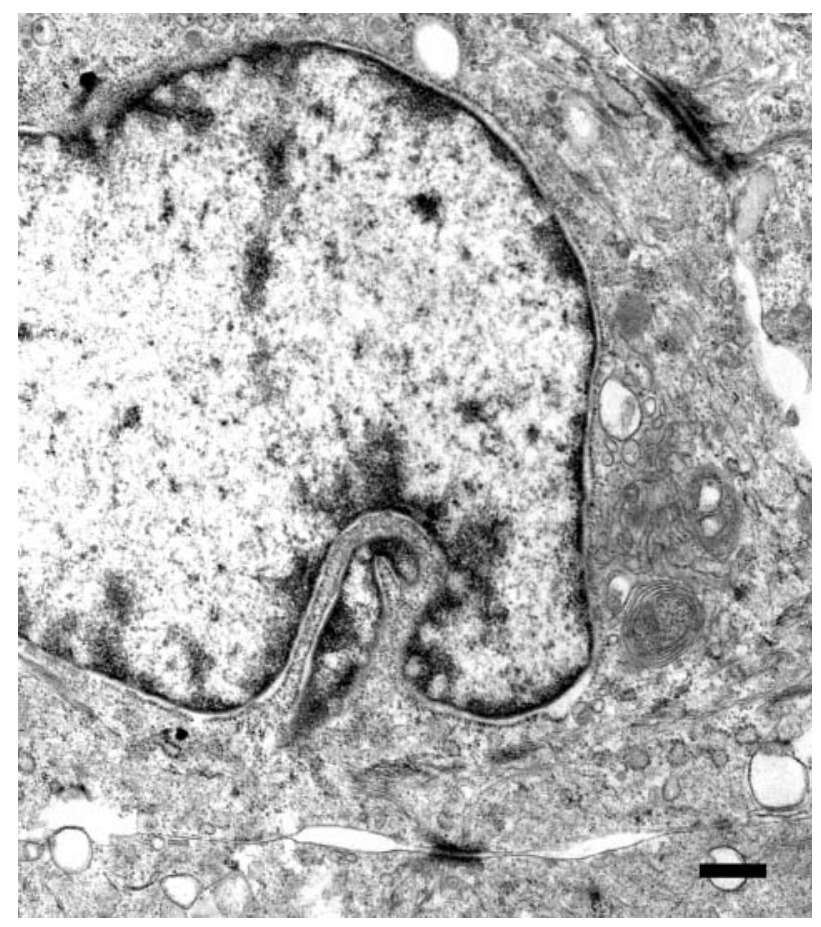

Fig. 4. Loggerhead Turtle No. 1, showing ultrastructural characteristics of neoplastic epithelial cell from the lungs with 2 desmosomes. Uranyl acetate counterstain. (Scale bar $=$ $0.44 \mu \mathrm{m})$

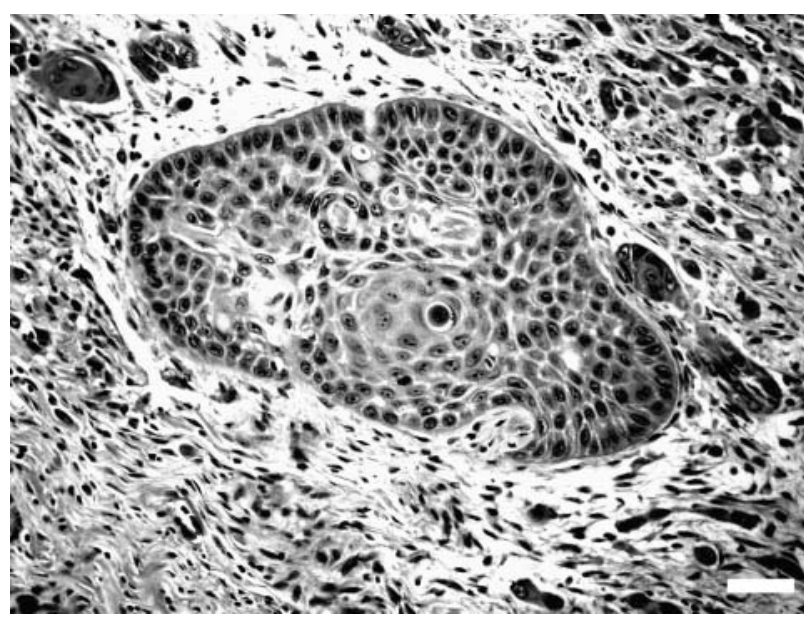

Fig. 5. Loggerhead Turtle No. 2, showing nests of anaplastic keratinocytes infiltrating the dermis. H\&E stain. (Scale bar $=$ $25 \mu \mathrm{m})$

neoplastic epithelial cells without individual keratinization were observed in skeletal muscle tissue, liver (Fig. 6), spleen, heart, lungs, and kidneys. No intercellular bridges were detected in the metastases. Some hepatic areas revealed a distorted structure with absence of distinct double plates of hepatic cells due to the infiltrative epithelial cells. The tumoral nests in the liver were smaller than those observed in other organs. However, mitosis of tumoral keratinocytes were frequently observed in the liver. The diagnosis was poorly differentiated squamous cell carcinoma with metastases to muscle tissue, liver, spleen, heart, lungs, and kidneys.

None of the tumoral cells of the selected samples were immunohistochemically positive with antisera against the high and low molecular weight cytoker-

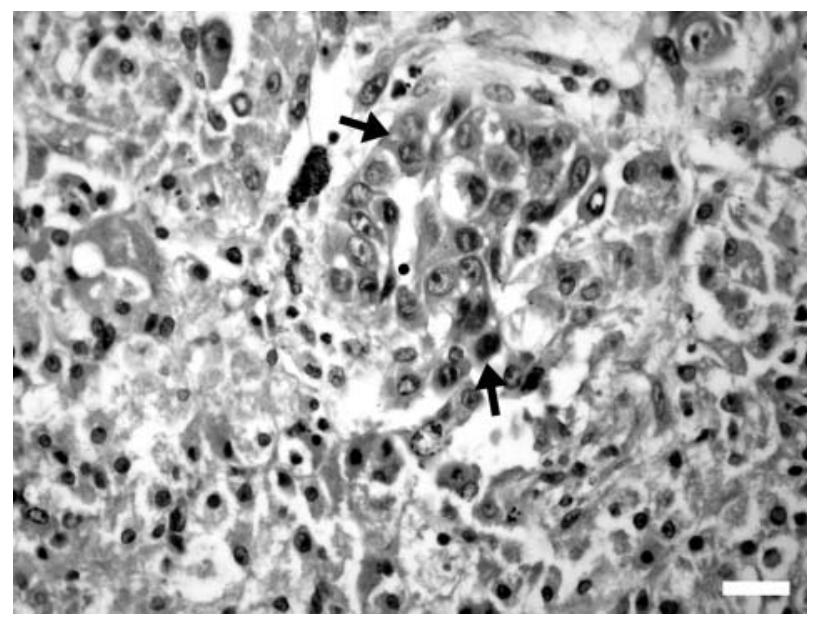

Fig. 6. Loggerhead Turtle No. 2, showing irregular cords of neoplastic epithelial cells infiltrating liver (arrows). H\&E stain. (Scale bar $=13 \mu \mathrm{m})$ 
atins, vimentin, and desmin. No immunoreactivity was seen with normal epithelial cells from the skin, lungs, and kidneys of these turtles.

Normal fibroblasts and striated muscle cells from these turtles showed mild immunoreactivity using the vimentin and desmine antisera respectively (Table 1). Normal tissues from mammals used as positive controls showed strong immunoperoxidase labelling with all these antisera.

\section{DISCUSSION}

Squamous cell carcinomas are uncommon in reptiles. In chelonians there are references to this type of tumor in the Ceylon terrapin Geoemyda trijuga (Cowan 1968) and the European pond turtle Emys orbicularis (Billups \& Harshbarger 1976). Both cases involved the integumentary system, but the pond turtle also had metastases in the liver. Recently, the effect of strontium-90 on squamous cell carcinoma in the eastern box turtle Terrapene carolina was described (Greenacre \& Roberts 2000). Squamous cell carcinoma has also been reported in snakes and lizards involving the oral cavity, cloaca, and integumentary system, none of which were reported to have been metastasized (Hill 1977, Jacobson 1981, Machotka 1984, Roberts et al. 1991, Ramsey \& Fowler 1992).

The tumors detected in our 2 sea turtles were diagnosed histologically as multiple squamous cell carcinomas with metastases to several tissues. Although metastases were detected in both cases, the degree of differentiation of these tumors was not the same. The first turtle had a well-differentiated SCC characterized by the presence of horn pearls and intercellular bridges. The second turtle had a poorly differentiated SCC characterized by absence of keratinization and marked intercellular bridges. Tumoral nests observed in the liver of the second turtle were smaller and more irregular than those detected in other organs. However, tumoral keratinocytes were frequently observed in the liver. Probably the hepatic metastases were the last to develop. There are no descriptions of multiple SCCs in reptiles. In mammals, multiple SCCs have been described in dogs and cats, mainly affecting the digits (Madewell et al. 1982, Brown et al. 1985), but the cause of such multiple occurrence has not been determined. In mammalian species, SCC is usually unicentric in middle-aged to older animals. However, our 2 sea turtles were juveniles. Since our findings could be related to a highly mutagenic environment, further studies determining the presence of environmental contaminants, pesticides, and heavy metals in the tissues of these turtles will be carried out.
Immunohistochemistry has proved a valuable tool for the accurate diagnosis of a number of tumors in mammals and birds (Kusewitt et al. 1997, Ramis et al. 1999). However, immunohistochemical characterization of neoplastic cells in reptiles has been reported in only a few cases. Cells comprising the melanoma of the death adder Acanthopis antarcticus proved S-100-negative, using a polyclonal rabbit antibovine S-100 antibody (Kusewitt et al. 1997). However, a malignant peripheral nerve-sheath tumor in the water moccasin Agkistrodon piscivorus was S-100-positive, whereas striated and smooth muscle cells were actin-positive, and nonmuscle mesenchymal cells were vimentin-positive, using commercially available antibodies from mammals (Ramis et al. 1998). Immunohistochemical characterization of neoplastic cells in our sea turtles was negative. Even the normal epithelial cells from the skin showed no immunoreactivity when antibodies against high and low molecular weight cytokeratins from mammals were used. However, normal fibroblasts and striated muscular cells of these turtles showed mild red immunoreactivity using the vimentin and desmin antisera respectively. The major protein components of scales and shell scute of reptiles are $\beta$-keratins (Wyld \& Brush 1983, Homer et al. 2001). The molecular weight of avian and certain reptilian $\beta$-keratins ranges from 10 to $30 \mathrm{kDa}$, whereas the molecular weight of $\alpha$-keratins of vertebrate epithelia ranges from 40 to $70 \mathrm{kDa}$ (Gregg \& Rogers 1986, Marshall et al. 1991). This could explain the absence of immunoreactivity in the epithelial cells of these sea turtles using antibodies against cytokeratins from mammals. However, the number of carcinomas in reptiles tested for cytokeratins is still too small to draw general conclusions.

Except for fibropapillomatosis, neoplasms are uncommon in sea turtles. Green turtle fibropapillomatosis (GTFP) is characterized by multiple cutaneous papillomas, fibromas, and fibropapillomas, as well as occasional visceral fibromas (Herbst et al. 1999). To our knowledge, our study constitutes the first description of squamous cell carcinoma in sea turtles. Further studies using polyclonal antisera to avian $\beta$-keratin are in progress to attempt to characterize these tumors immunohistologically.

Acknowledgements. The authors would like to thank P. Castro and J. F. Arbelo, Department of Morphology, University of Las Palmas de Gran Canaria, for technical assistance. We are grateful to members of Viceconsejería de Medio Ambiente, Cabildo Insular de Gran Canaria, for providing us with the turtles. We thank F. Freire of the Electron Microscopy Service, University of Las Palmas de Gran Canaria, for preparing the specimens for the electron microscopy and preparation of electron photomicrographs. This study was partially supported by the national project I + D REN2000-1753 MAR, and the Consejería de Política Territorial y Medio Ambiente del Gobierno de Canarias. 


\section{LITERATURE CITED}

Bancroft JD, Stevens A (1996) Theory and practice of histological techniques, 4th edn. Churchill Livingstone, New York

Billups LH, Harshbarger JC (1976) Neoplasia: reptiles. In: Melby EC, Altman NH (eds) Handbook of laboratory science, Vol 2. CRC Press, Cleveland, OH, p 346-356

Boch J, Supperer R (1982) Generalidades. In: Boch J, Supperer R (eds) Parasitología en medicina veterinaria. Hemisferio Sur S-A, Buenos Aires, p 1-47

Brown PJ, Hoare CM, Rochlitz I (1985) Multiple squamous cell carcinoma of the digits in two cats. J Small Anim Pract 26:323-328

Cowan DF (1968) Diseases of captive reptiles. J Am Vet Med Assoc 153:848-859

Green DE, Harshbarger JC (2001) Spontaneous neoplasms in amphibians. In: Wright KM, Whitaker BR (eds) Amphibian medicine and captive husbandry. Krieger Publishing, Malabar, FL, p 335-400

Greenacre CB, Roberts R (2000) Effect of strontium-90 on squamous cell carcinoma in an eastern box turtle (Terrapene carolina); discussion of alternative treatment modalities. In: Proceedings of the 3rd International Virtual Conference in Veterinary: Diseases of Reptiles and Amphibians. Georgia University, Athens

Gregg K, Rogers GE (1986) Feather keratin: composition, structure and biogenesis. In: Bereiter-Hann J, Matoltsy AG, Richards KS (eds) Biology of the integument, Vol 2. The vertebrates. Springer-Verlag, Berlin, p 666-694

Hafner S, Harmon BG, Stewart RG, Rowland GN (1993) Avian keratoacanthoma (dermal squamous cell carcinoma) in broiler chicken carcasses. Vet Pathol 30:265-270

Harshbarger JC (1979) Activities report registry of tumors in lower animals, 1978 supplement. Smithsonian Institute Press, Washington, DC

Harshbarger JC (2002) Marine turtle fibroma and fibropapilloma cases in the registry of tumors in lower animals. In: McKinnell RG, Carlson DL (eds) Proceedings of the 6th International Symposium on Pathology of Reptiles and Amphibians. University of Minnesota Printing Services, Saint Paul, p 129-143

Harshbarger JC, Trauth ST (2002) Squamous cell carcinoma upgrade of the epidermal papilloma reported in an Ozark hellbender (Cryptobranchus alleganiesis bishopi). In: McKinnell RG, Carlson DL (eds) Proceedings of the 6th International Symposium on Pathology of Reptiles and Amphibians. University of Minnesota Printing Services, Saint Paul, p 43-48

Herbst LH, Jacobson ER, Klein PA, Balazs GH, Moretti R, Brown T, Sundberg JP (1999) Comparative pathology and pathogenesis of spontaneous and experimentally induced fibropapillomas of green turtles (Chelonia mydas). Vet Pathol 36:551-564

Editorial responsibility: Perneel Zwart, Utrecht, The Netherlands
Hill JR (1977) Oral squamous cell carcinoma in a California king snake. J Am Vet Med Assoc 171:981-982

Homer BL, Li C, Berry KH, Denslow ND, Jacobson ER, Sawyer RH, Williams JE 2001) Soluble scute proteins of healthy and ill desert tortoises (Gopherus agassizii). Am J Vet Res 62:104-110

Jacobson ER (1981) Neoplastic diseases. In: Cooper JE, Jackson OF (eds) Diseases of the Reptilia, Vol 2. Academic Press, San Diego, p 429-468

Jacobson ER (1991) An update on green turtle fibropapilloma. In: Balazs GH, Pooley SG (eds) Research plan for marine turtle fibropapilloma. NOAA-TM-NMFS-SWFSC-156. National Oceanographic and Atmospheric Administration, Honolulu, p 59-71

Kusewitt DF, Reece RL, Miska KB (1997) S-100 immunoractivity in melanomas of two marsupials, a bird, and a reptile. Vet Pathol 34:615-618

Latimer KS (1994) Oncology. In: Ritchie BW, Harrison GJ, Harrison LR (eds) Avian medicine: principles and application. Wingers, Lake Worth, FL, p 640-672

Machotka SV (1984) Neoplasia in reptiles. In: Hoff GL, Frye FL, Jacobson ER (eds) Diseases of amphibians and reptiles. Plenum Press, New York, p 519-580

Madewell BR, Pool RR, Theilen GH, Brewer WG (1982) Multiple subungual squamous cell carcinomas in five dogs. J Am Vet Med Assoc 180:731-734

Marshall RC, Orwin DFG, Gillespie JM (1991) Structure and biochemistry of mammalian hard keratin. Electron Microsc Rev 4:47-83

Pulley T, Stannard AA (1990) Tumors of the skin and soft tissues. In: Moulton JE (ed) Tumors in domestic animals, 3rd edn. University of California Press, Berkeley, p 23-87

Ramis A, Pumarola M, Fernández-Morán J, Añor S, Majó N, Zidan A (1998) Malignant peripheral nerve sheath tumor in a water moccasin (Agkistrodon piscivorus). J Vet Diagn Investig 10:205-208

Ramis A, Gibert X, Majó N, Grifols J (1999) Metastatic oral squamous cell carcinoma in a Montagu's harrier (Circus pigargus). J Vet Diagn Investig 11:191-194

Ramsay EC, Fowler M (1992) Reptile neoplasms at the Sacramento zoo, 1981-1991. In: Junge RE (ed) Proceedings of the Joint Conference of the American Association of Zoo Veterinarians \& the American Association of Wildlife Veterinarians, Oakland, CA, p 153-155

Roberts WG, Klein MK, Loomis M, Weldy S, Berns MW (1991) Photodynamic therapy of spontaneous cancers in felines, canines, and snakes with chloro-aluminium sulfonated phthalocyanine. J Natl Cancer Inst 83:18-23

Wolke RE, George A (1981) Sea turtle necropsy manual. NOAA Technical Memorandum NMFS-SEFC-24, National Oceanic and Atmospheric Administration, Kingston, RI

Wyld JA, Brush AH (1983) Keratin diversity in the reptilian epidermis. J Exp Zool 225:387-396

Submitted: October 8, 2002; Accepted: October 15, 2003

Proofs received from author(s): February 2, 2004 